\title{
Study on buck evaluation based on semen quality and fertility
}

\author{
F Sultana, SS Husain, A Khatun, AS Apu, MAMY Khandoker*
}

Department of Animal Breeding and Genetics, Bangladesh Agricultural University, Mymensingh 2202, Bangladesh

\begin{abstract}
The experiment was conducted to evaluate the performance of buck on the basis of semen quality and fertility. Data on 162 ejaculates from five adult Black Bengal bucks (B1, B2, B3, B4 and B5) were recorded. Individual buck effect was found to be significant on semen volume $(p<0.05)$, three stages of sperm motility $(p<0.01)$ and percentage of live sperm $(p<0.01)$ but insignificant $(p>0.05)$ on sperm concentration and percentage of normal sperm. The results of semen volume per ejaculate, sperm concentration, initial sperm motility, on dilution sperm motility, post-thawing sperm motility, percentage of live sperm and percentage of normal sperm were ranged from $0.58 \pm 0.17$ to $1.04 \pm 1.1 \mathrm{ml}, 2827 \pm 0.76$ to $3132 \pm 0.88 \mathrm{million} / \mathrm{ml}, 77.07 \pm 1.06$ to $81.47 \pm 1.84 \%, 61.71 \pm 1.03$ to $70.30 \pm 1.54 \%, 48.15 \pm 1.99$ to $55.88 \pm 2.97 \%, 87.58 \pm 0.96$ to $92.95 \pm 0.74 \%$ and $87.17 \pm 2.40$ to $91.85 \pm 1.38 \%$, respectively. The significantly $(p<0.05)$ highest volume of semen, three stages of sperm motility and percentage of live sperm was found in buck B5 and lowest in buck B1. The significantly $(p<0.05)$ highest non-return rate was found in buck B5 $(87.31 \pm 7.99 \%)$ and lowest in buck B1 $(63.41 \pm 672 \%)$. There was no significant $(p>0.05)$ seasonal variation was observed on semen characteristics except on dilution sperm motility and post-thawing sperm motility which differed significantly $(p<0.05)$. The season had no significant $(p>0.05)$ effect on 25 day non-return rate of bucks. The results of the present study revealed that evaluation of breeding bucks based on semen quality is important and provides the guideline to buck evaluation for reproductive performance.
\end{abstract}

Key words: Buck, semen quality, non-return rate

Bangladesh Animal Husbandry Association. All rights reserved.

Bang. J. Anim. Sci. 2013. 42 (2): 101-108

\section{I ntroduction}

Selection of buck represents the starting point in goat development program. Selection of male is much more important because a buck can produce thousands of kids a year through artificial insemination $(\mathrm{Al})$, therefore the main avenue for genetic improvement is the selection of breeding male (Ahmed and Islam, 1987). For better propagation of the species of goat, there should have good breeding buck. But unfortunately, there is severe shortfall of stud bucks all over the country, especially in the rural areas, where more than $80 \%$ goats are being reared by the farmers. It is evident that about $30 \%$ does remain without service due to lack of breeding buck available in the locality. In most situations, bucks are being kept by only a few lower cast people and animals are often genetically very poor with unknown pedigree. Moreover, same buck has been used generation after generation which has created greater chance of increasing inbreeding and hence lowering reproductive performances along with disseminating of various venereal and infectious diseases (Husain 2007).

In order to improve the genetic makeup of goats, the poor quality semen producing buck must be avoided from insemination. Therefore, the aim of the present study was to evaluate the semen quality of Black Bengal bucks and also to investigate the effect of season on semen quality and fertility in respect of non-return rate (NRR).

\section{Materials and Methods}

The experiment was carried out at the Artificial Insemination Centre under the Department of Animal Breeding and Genetics, Bangladesh Agricultural University, Mymensingh during the 


\section{Semen quality and fertility of buck}

period from 2008 to 2009. Five adult Black Bengal bucks (aged between 18 to 22 months) were taken for this experiment and were numbered as B1, B2, B3, B4 and B5. The body weight and scrotal circumference of bucks were 19 to $22 \mathrm{~kg}$ and 17.5 to $20 \mathrm{~cm}$ respectively. The bucks were reared in individual pen of size 4.25 square feet and animal received $100 \mathrm{~g}$ commercial concentrate in pellet form (crude protein content: $120 \mathrm{~g} / \mathrm{kg} D M$ and energy content: $10.4 \mathrm{MJ} \mathrm{ME} / \mathrm{kg} \mathrm{DM}), 50 \mathrm{~g}$ gram and $1.5 \mathrm{~kg}$ green grass (Napier and/ or German) in the morning and in the afternoon daily allowance of $100 \mathrm{~g}$ commercial concentrate, $1.5 \mathrm{~kg}$ green grass per head daily were given. Clean and safe water was given ad libitum. The bucks were allowed for grazing and exercise for 1-2 hours daily. Does were reared in semi-intensive management system. They fed on free grazing on pasture and minimum concentrate was supplemented $(80 \mathrm{~g}$ pellet/head in the morning) and $40 \mathrm{~g} \mathrm{gm} /$ head in the evening). Regular deworming with ivermectin (thrice in a year) and vaccination against Peste des petitsrumianants (PPR) was performed for bucks and does.

Semen was collected by artificial vagina (AV) method twice a week within 8.30 am from each buck. Semen samples were collected in a graduated transparent collection tube covered by an insulating jacket and kept in a water bath $\left(37^{\circ} \mathrm{C}\right)$ immediately after collection for further evaluation. Evaluation of fresh semen was done using the method described by Herman and Madden (1963). The volume of ejaculates $(\mathrm{ml})$ was recorded from the graduated collection vials. The color and opacity of the semen and presence of any foreign body, such as pus were checked. Motility of raw semen or mass activity (\%) was examined by examining a drop of raw undiluted semen on a pre-warmed $\left(37^{\circ} \mathrm{C}\right)$ slide under a light microscope at $4 x$ magnification. The concentration of spermatozoa in semen sample (million/ml) was estimated by haemocytometer method accordceptioning to Herman and Madden (1963). Eosin-nigrosin stain was used for counting live spermatozoa whereas Rose Bengal stain was used for counting normal spermatozoa in semen according to Herman and Madden (1963). Semen with motility of more than $60 \%$ was diluted with freezing extenders egg yolk citrate diluter. Semen was diluted on the basis of volume and sperm concentration per ejaculate to obtain a final concentration of 100 million spermatozoa per insemination dose. The motility (\%) of the diluted semen was observed and recorded. Semen was then packed manually into $0.5 \mathrm{ml}$ straw and the laboratory ends of the straws were sealed with polyvinyl chloride (PVC) powder. The straws were placed in the refrigerator at $4-5^{\circ} \mathrm{C}$ for 3 hours. The motility of the equilibrated sperm was checked and only samples with more than $60-70 \%$ were used for freezing. After equilibration the straws were placed horizontally on a rack and transferred to the freezer to be frozen in vapor $15-20 \mathrm{~cm}$ above the liquid nitrogen (LN.). After 30 minutes, the frozen straws were transferred into the canister within the liquid nitrogen containers at $-196^{\circ} \mathrm{C}$ until use for Al. After 24 hours, straws were retrieved from the LN containers using forceps and thawed in water bath at $37^{\circ} \mathrm{C}$ for 12 seconds and post-thaw motility was recorded.

Artificial insemination with frozen semen was performed in BAU Al centers. The number of does inseminated with frozen semen by buck B1, B2, B3, B4 and B5 were 49, 50, 50, 54 and 42, respectively.

Non-return rate (NRR) was estimated using the following formula:

$\operatorname{NRR}(\%)=$

$\frac{\text { No. served does not required further service for a given conception }}{\text { No.served does }} \times 100$

To evaluate the seasonal variations on semen quality and fertility, the experimental period was divided into 3 seasons, i.e. summer (March to June), rainy (July to October) and winter (November to February).

The data generated were analyzed for ANOVA using a completely Randomized Design with the help of Statistical Analysis System (SAS, 1998) Computer Package and DMRT (Duncan's Multiple Range Test) was performed to identify significant differences among the mean values with the help of SAS, 1998. 
Sultana et al. (2013) Bang. J. Anim. Sci. 42 (2): 103- 108

\section{Results and discussion}

Table 1 showed that mean of semen volume per ejaculate ranged from $0.58 \pm 0.17$ to $1.04 \pm 0.11 \mathrm{ml}$. Semen volume per ejaculate differed significantly $(p<0.05)$ among the bucks. Highest semen volume was obtained in buck B5 followed by B2, B3, B4 and $B 1$. The estimated values were $1.04 \pm 0.11 \mathrm{ml}$, $0.75 \pm 0.09 \mathrm{ml}, 0.74 \pm 0.11 \mathrm{ml}, 0.65 \pm 0.13 \mathrm{ml}$ and $0.58 \pm 0.17 \mathrm{ml}$ for B5, B2, B3, B4 and B5, respectively. The five bucks belonged to the same breed and of similar age their management and nutritional status and general health condition were also similar. So, the difference in volume of semen might reflect their different genetic potentiality and genetically superior bucks could produce higher volume of semen. The result of the present study agrees with the studies of previous workers (Das et al. 2006; Barbas et al. 2006; Bakshi et al. 1987; Mittal 1982). Apu al. (2008) and Karim (2008) also reported a significant $(p<0.05)$ individual variation on semen volume of Black Bengal bucks.

The concentration of spermatozoa per $\mathrm{ml}$ of semen did not differ significantly $(p>0.05)$ among the bucks. The higher sperm concentration was observed in buck B5, followed by B3, B2, B4 and $B 1$ in the order of $3132 \pm 0.88 \times 10^{6}$, $3003 \pm 1.00 \times 10^{6}, 2978 \pm 0.84 \times 10^{6}, 2952 \pm 1.31 \times 10^{6}$ and $2827 \pm 0.76 \times 10^{6} / \mathrm{ml}$ respectively (Table 1 ). The insignificant difference in sperm concentration among the bucks in the present study indicated the equal fitness of all bucks in terms of sperm concentration. This result corroborates well with the result of Karim (2008), Afroz (2005), Singh et al. (1985) who found insignificant buck effect on sperm concentration.
In case of initial motility the highest sperm motility was found in B5 $(81.47 \pm 1.84 \%)$ and the lowest in B1 $(77.07 \pm 1.06 \%)$. The analysis of variance revealed that buck to buck variation was highly significant $(p<0.01)$ in initial sperm motility (Table 1 ). The difference in sperm motility might be due to individual variation. The previous workers (I slam et al. 2007; Das et al. 2006) also found significant variation in initial sperm motility among the bucks.

The average values with standard errors of dilution and post-thawing sperm motility are also shown in Table 1. On dilution and post-thawing sperm motility also showed significant $(p<0.01)$ difference among the bucks and B5 again found as the best performer among the bucks in these two criteria. The result of the present study is confounded with the results of Karim (2008) who reported a significant buck effect on diluted semen motility and the value ranged from $70.00 \pm 0.00$ to $73.75 \pm 2.45 \%$. Similar observation was also reported from the studies of Apu et al. (2008). Considering post-thaw sperm motility, the present study is in agreement with the studies of Karim (2008) who found significant individual variation and the value ranged from $57.50 \pm 8.00$ to $67.75 \pm 2.00 \%$. The result of the present study is also in agreement with findings of Gacitua and Arav (2005) who reported 55-65\% post-thaw sperm motility. The individual variation in motility of spermatozoa suggest that this character may be taken into consideration while selecting bucks because motility is an important criteria for the quality of semen and it also determines the fertility of bucks (Nazir 1988).

Table 1. Mean \pm standard error (SE) of semen quality of individual

\begin{tabular}{|c|c|c|c|c|c|c|c|}
\hline \multirow[t]{2}{*}{ Buck No } & \multirow[t]{2}{*}{ Volume (ml) } & \multirow{2}{*}{$\begin{array}{l}\text { Sperm conc. } \\
\text { (million/ml) }\end{array}$} & \multicolumn{3}{|c|}{ Sperm motility (\%) } & \multirow{2}{*}{$\begin{array}{l}\text { Live sperm } \\
(\%)\end{array}$} & \multirow{2}{*}{$\begin{array}{c}\text { Normal } \\
\text { sperm (\%) }\end{array}$} \\
\hline & & & Initial & On dilution & Post-Thawing & & \\
\hline B1 (32) & $0.58^{\mathrm{b}} \pm 0.17$ & $2827 \pm 0.76$ & $77.07^{\mathrm{b}} \pm 1.06$ & $61.71^{\mathrm{C}} \pm 1.03$ & $48.15^{\mathrm{b}} \pm 1.99$ & $87.58^{c} \pm 0.96$ & $87.17 \pm 2.40$ \\
\hline B2 (31) & $0.75^{\mathrm{ab}} \pm 0.09$ & $2987 \pm 0.84$ & $80.17^{\mathrm{ab}} \pm 1.41$ & $66.55^{\mathrm{b}} \pm 1.18$ & $53.73^{\mathrm{ab}} \pm 1.91$ & $90.09^{\mathrm{ab}} \pm 0.62$ & $90.21 \pm 1.60$ \\
\hline B3 (33) & $0.74^{\mathrm{ab}} \pm 0.11$ & $3003 \pm 1.00$ & $77.93^{\mathrm{ab}} \pm 1.19$ & $65.69^{b} \pm 0.89$ & $52.69^{\mathrm{ab}} \pm 2.27$ & $90.36^{\mathrm{b}} \pm 0.64$ & $89.44 \pm 1.54$ \\
\hline B4 (34) & $0.65^{b} \pm 0.13$ & $2952 \pm 1.34$ & $77.90^{\mathrm{ab}} \pm 1.23$ & $65.37^{b} \pm 0.99$ & $48.83^{\mathrm{b}} \pm 1.71$ & $90.11^{\mathrm{b}} \pm 0.55$ & $78.75 \pm 1.83$ \\
\hline B5 (32) & $1.04^{\mathrm{a}} \pm 0.11$ & $3132 \pm 0.88$ & $81.47^{\mathrm{a}} \pm 1.84$ & $70.30^{\mathrm{a}} \pm 1.54$ & $55.88^{\mathrm{a}} \pm 2.97$ & $92.95^{\mathrm{a}} \pm 0.74$ & $91.85 \pm 1.38$ \\
\hline Sig, level & * & NS & $* *$ & $* *$ & $* *$ & $* *$ & NS \\
\hline
\end{tabular}

Means with different superscripts within the same column differed significantly $(*, p<0.05 ; * *, p<0.01 ;$ NS, Nonsignificant; Figures in the parenthesis indicate the number of observation 


\section{Semen quality and fertility of buck}

From Table 1 , it was found that the mean percentage of live spermatozoa varied form $87.58 \pm 0.96$ to $92.95 \pm 0.74 \%$ which differed significantly $(p<0.01)$ among the different bucks. However, semen of buck B5 possesses the highest live spermatozoa $(92.95 \pm 0.74 \%)$ where as B1 possesses the lowest $(87.58 \pm 0.96 \%)$ spermatozoa. In this study the bucks were of same breed, age, their health condition and overall management were same. This variation in percentage of live spermatozoa might be due to the individual variation. This result is coincided with the findings of Apu et al. (2008) and Husain (2007) who obtained $83.73 \pm 0.94$ to $89.27 \pm 1.40 \%$ and $84.99 \pm 0.38$ to $85.62 \pm 0.57 \%$ live spermatozoa in Black Bengal semen which is slightly lower than the present study. The variation in percent of live sperm indicates the genetic superiority of individual buck as the percent of live sperm is positively correlated with fertility (Barbas et al. 2006).

While considering percentage of normal sperm, no significant $(p>0.05)$ difference was observed among the buck (Table 1). Although the buck were statistically similar, the higher percentage $(91.85 \pm 1.38 \%)$ of normal sperm was noted in B5 and lower $(87.17 \pm 2.40 \%)$ in $\mathrm{B} 1$. The insignificant difference in percentage of normal sperm of buck indicated the equal potentiality of all buck in terms of percentage of normal sperm. The findings of the present study corroborated with the results of Apu (2008) who reported $91.27 \pm 0.47$ to $92.08 \pm 0.39 \%$ of normal sperm and the difference in buck to buck is insignificant. The present result also agreed with the findings of Singh et al. (1985) who reported 91.07\% normal spermatozoa in Black Bengal Buck semen. On the other hand, Afroz (2005) reported the average percentage of normal spermatozoa varied from $89.72 \pm 0.35$ to $91.16 \pm 0.36 \%$ which is almost similar to the present study. Among five bucks, B5 was screened as the best performer on the basis of semen quality and this buck might have good genetic potentiality than others deserving further study for confirmation.

The average non-return rate (NRR) to first insemination is presented in Figure 1 and variation among the bucks was found to be significant $(p<0.05)$. The highest NRR was obtained in buck B5 (85.71 $\pm 7.99 \%)$ followed by B2 $(80.00 \pm 6.02 \%)$, B3 $(76.00 \pm 10.43 \%)$, B4 $(63.26 \pm 6.98 \%)$ and B1
$(62.96 \pm 6.72 \%)$. The variation in fertility of bucks shows the individual potentiality of each buck. The result of the present study was in agreement with the findings of Paulenez et al. (2003) who found $87 \%$ 25-day NRR in Norwegian dairy goats. Again, Chauhan and Anand (1990) reported 81\% conception rate with frozen Jamnapari buck semen which is in close agreement with the present study. On the other hand Karim (2008) found $55.90 \%$ conception rate with frozen semen. Similarly, Dorado et al. (2007) obtained $42.9 \%$ conception rate which were lower than the present study. This variation might be due to the fact that, they obtained conception rate by actual pregnancy diagnosis whereas, conception rate in this study was determined by non-return basis. Among the five bucks, buck B5 was screened as the best performer whereas B2, B3 were moderate, B4 was poor and B1 was the poorest performer. It was important to note that the fertility of same buck (buck B5) was best which ultimately reflect its genetic superiority.

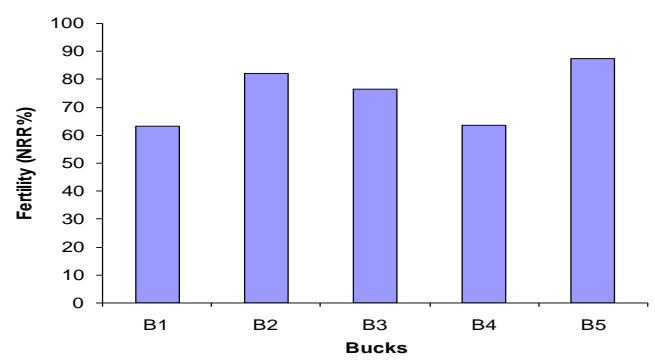

Figure 1. Fertility (NRR \%) of different bucks

Table 2 showed the effect of season on different semen qualities of bucks. The volume of semen per ejaculate did not differ significantly $(p>0.05)$ among the season. But the higher volume of semen $(0.91 \pm 0.08 \mathrm{ml})$ was found in winter season and lower $(0.66 \pm 0.1 \mathrm{ml})$ in rainy season (Table 2 ). The result of the present study was in agreement with the findings of Maina et al. (2006). Alessandro et al. (2001) and Kumi-Diaka et al. (1981) reported an insignificant seasonal variation on semen volume. According to Mainaet et al. (2006) higher volume was found in dry season $(1.08 \pm 0.48 \mathrm{ml})$ and lower volume in rainy season $(1.01 \pm 0.48 \mathrm{ml})$ which was higher than the present study. This difference might be due to difference in age, breed, feeding regime etc. 
Sultana et al. (2013) Bang. J. Anim. Sci. 42 (2): 103- 108

Table 2. Effect of season on semen quality (Mean \pm SE) in Black Bengal goat

\begin{tabular}{lccc}
\hline Parameters & \multicolumn{3}{c}{ Season } \\
\cline { 2 - 4 } & Winter & Summer & Rainy \\
& $(54)$ & $(54)$ & $(54)$ \\
\hline V/E (ml) & $0.91 \pm 0.08$ & $0.72 \pm 0.09$ & $0.66 \pm 0.10$ \\
SC (10 $/ \mathrm{ml})$ & $4002 \pm 0.67$ & $3036 \pm 0.69$ & $3065 \pm 0.78$ \\
SM (\%) & & & \\
-Initial & $77.23 \pm 0.94$ & $78.88 \pm 0.97$ & $79.29 \pm 1.09$ \\
-On dilution & $64.15^{\mathrm{b}} \pm 1.5$ & $65.57^{\mathrm{ab}} \pm 0.85$ & $66.63^{\mathrm{a}} \pm 0.95$ \\
-Post-thawing & $47.22^{\mathrm{b}} \pm 1.15$ & $53.55^{\mathrm{a}} \pm 1.54$ & $53.28^{\mathrm{a}} \pm 0.58$ \\
LS (\%) & $89.80 \pm 0.51$ & $90.63 \pm 0.52$ & $91.09 \pm 0.58$ \\
NS (\%) & $88.37 \pm 1.22$ & $91.69 \pm 1.25$ & $89.33 \pm 1.41$ \\
\hline
\end{tabular}

Figures in the parenthesis indicate the number of observation; V/E, volume per ejaculation; SC, sperm concentration; SM, sperm motility; LS, live sperm; NS, normal sperm; Means with different superscripts within the same row differed significantly $(P<0.05)$

From the Table 2 it was found that season has no significant $(p>0.05)$ effect on sperm concentration, although the higher sperm concentration was found in winter $\left(4002 \pm 0.67 \times 10^{6} \mathrm{million} / \mathrm{ml}\right)$. Maina et al. (2006) reported an insignificant difference which is an agreement with the present study who found higher sperm concentration in dry season $\left(3.75 \pm 0.51 \times 10^{9} \mathrm{ml}\right)$ and lower in wet season $\left(2.67 \pm 0.51 \times 10^{9} \mathrm{ml}\right)$. The cause of this discrepancy might be due to difference in age and breed. However, these findings were supported by others researches (Chang et al., 2006 and Alessandro, 2001).

Again, Table 2 showed that initial sperm motility of the bucks did not vary significantly $(p>0.05)$ among the seasons. However, comparatively higher motility was observed in summer season $(79.29 \pm 1.09 \%)$ rest in the order was in the rainy season $(78.88 \pm 0.97 \%)$ and winter season $(77.23 \pm 0.94 \%)$. Srinivas et al. (2002) reported an insignificant seasonal variation on initial motility and the average value ranged from $4.34 \pm 0.08$ to $4.46 \pm 0.06 \%$. On the other hand, the motility of spermatozoa in diluted semen revealed a significant $(p<0.05)$ seasonal variation which agrees with the study of Saxena and Tripathi (1984) and Verma et al. (1991).
The results of post-thawing motility in different seasons are also shown in Table 2 Significant $(p<0.05)$ variation on post-thaw motility was observed between summer and winter season. The best motility was observed in summer $(53.55 \pm 1.54 \%)$ followed by rainy $(53.28 \pm 0.58 \%)$ and winter season $(47.22 \pm 1.5 \%)$. The highest post-thawing sperm motility was observed in summer which again supports the findings of highest on dilution sperm motility in the same season. El- Saidy (2004) reported high post-thaw motility in summer season. Although the initial sperm motility did not show any significant difference, on dilution sperm motility and postthawing sperm motility show significant seasonal variation. This might be due to processing and freezing effect of semen.

With regard to the percentage of live sperm an insignificant $(p>0.05)$ seasonal effect was found in this study (Table 2). Although the effect of season on percentage of live spermatozoa is statistically similar but the higher percentage of live sperm was found in rainy season $(91.09 \pm 0.58 \%)$ followed by summer $(90.63 \pm 0.52 \%)$ and winter season $(89.80 \pm 0.51 \%)$. The result of the present study is corroborated well with the findings of Mainaet et al., (2006), Kamal et al., (2005). Mainaet et al., (2006) reported average percent of live spermatozoa in dry season to be $87.5 \pm 0.75 \%$ and the variation among the season is insignificant.

Again, insignificant $(p>0.05)$ seasonal variation was found in percentage of normal spermatozoa with the higher percentage of normal spermatozoa was found in summer $(91.69 \pm 1.25 \%)$ then in rainy $(89.33 \pm 1.4 \%)$ and winter season $(88.37 \pm 1.22 \%)$ respectively (Table 2 ). The result of the present study is in agreement with Kumi-Diakaet et al. (1981).

In temperate region, goats are seasonal breeders and the sexual activities of bucks as well as the quality and quantity of semen are affected unlike the tropics where goat breeds year round. Those regions located in latitude $10^{\circ}$ do not present significant seasonal variation (Roca et al., 1992). Again, Grayling et al. (1983) reported that in latitude below $30^{\circ}$ goat bucks do not show 


\section{Semen quality and fertility of buck}

any seasonal variation in semen production. As Bangladesh located in latitude $24^{\circ}$ we can conclude that there is no seasonal variation on the semen characteristics of Black Bengal Buck.

A total of 216 inseminated does were included in this study to ascertain the buck fertility in three seasons. The fertility of bucks in three seasons showed that there was no significant $(p>0.05)$ variation in NRR among three seasons with the

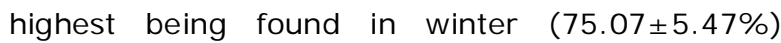
followed in order by summer $(74.1 \pm 5.60 \%)$ and rainy season $(74.04 \pm 6.30 \%$, Figure 1$)$. As there no significant difference was found, the buck semen could be used round the year. Restall (1991) and Chemineau and Zande (1982) reported that breeds in the tropics or subtropics may breed at all times of the year. Information in this regard is limited demands further study for confirmation.

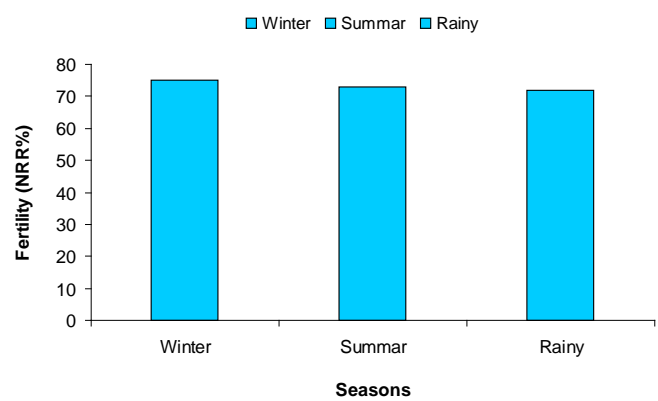

Figure 2. Fertility of bucks in three seasons

\section{Conclusion}

From the result it may be concluded that evaluation of breeding bucks based on semen quality is important and provides the guideline to buck evaluation for reproductive performance.

\section{Acknowledgment}

We gratefully acknowledged the United State Department of Agriculture (USDA) for financial support to perform this research work.

\section{References}

Afroz S (2005). Cryopreservation of buck semen. MS Thesis, Department of Animal Breeding and Genetics, Bangladesh Agricultural University, Mymensingh.
Ahmad N, Noakes ED (1996). Seasonal variations in the semen quality of young British goats. British Veterinary Journal, 152: 225-236.

Ahmed Z, Islam TH (1987). Cattle breeding program through artificial insemination in Bangladesh. Al Extension Project Report. Central Cattle Breeding Station, Savar, Dhaka. P. 24-61.

Alessandro AG, Cataldo P, Martemucci G (2001). Seasonal variations in semen characteristics of suffolk rams reared in Southern dry hot temparature zone (41 degrees $N$ ). Zooteenica-e-Nutrizione- Animal, 27: 231 239.

Al-Ghalban AM, Tabbaa MJ, Kridli RT (2004). Factors affecting semen characteristics and scrotal circumference in Damascus bucks. Small Ruminant Research, 53: 141-149.

Apu AS, Khandoker MAMY, Husain SS, Rahman SMHA, Notter RD (2008). Investigation of seminal attributes and fertility of Black Bengal goat. Bangladesh Journal of Animal Science, 37: 17-24.

Bakshi SA, Patil VK, Srivas AK, Jagtap DZ, More BK (1987). Studies on semen evaluation and fertility rate of Angora and 7/8 Angora bucks. Livestock Adviser, 12: 13-18.

Barbas PJ, Marques CC, Baptista CM, Vasques IM, Pereira MR, Cavaco-Gonclaves S, Mascarenhas MR, Natipoulin, Congie Y, Hortu MEA (2006). Reproduction in goat Sarrana breed: Seasonal and individual factors affecting fresh and frozen semen performance, in vivo and in vitro fertility. In. Animal products from the Mediterranean area, Wageningen Academic Publishers-Netherlands, 119: 337-342.

Chang YC, Jung, GK Song RC, Dong SS, Young KK, Balasubramanian S, Sang YC, Gyu JR (2006). Influence of seasons, entenders slow and rapid freezing on seminal characters in korean Native Bucks. Reproduction of Domestic Animals, 41: 55-60.

Chauhan MS, Anand SR (1990). Effect of egg yolk lipids on freezing goat semen. Theriogenology, 34: 1003-1013.

Chemineau P, Zande A (1982). Reproductive efficiency of Creole meat goatspermanantly kept with males. Relationship to a tropical 
Sultana et al. (2013) Bang. J. Anim. Sci. 42 (2): 103- 108

environment. Tropical Animal Production, 7: 98- 104.

Christensen P, Brockhoff PB, Lehn-Jensen H (1999). The relationship between semen quality and the non-return rate of bulls. Reproduction of Domestic Animals, 34: 503507.

Correa JR, Pace MM, Zavos PM (1997). Relationships among frozen thawed sperm characteristics assessed via the routine fertility of bulls in an Artificial tests and nation program. Theriogenology, 48: 721-731.

Das SK, Husain SS, Amin MR, Munim T, Hoque MA, Khandoker MAMY (2006). Growth performance of progeny using selected Black Bengal bucks. Bangladesh Journal of Animal Science, 35: 27- 35.

Dorado J, Rodríguez I, Hidalgo M (2007). Cryopreservation of goat spermatozoa: Comparison of two freezing extenders based on post-thaw sperm quality and fertility rates after artificial insemination. Theriogenology, 68: 168-77.

El-Saidy BE (2004). Seasonal variation in reproductive performance of crossbred Finnish rams (Finnish $\times$ Rahmani) in Egypt. Alenandria J ournal of Agricultural Research, 49: 11-24.

Gacitua H, Arav A (2005). Successful pregnancies with directional freezing of large volume buck semen. Theriogenology, 63: 931-8.

Grayling JPC, Grobbelaar JAN (1983). Seasonal variation in semen quality of Boer and Angora goat rams using different collection techniques. South African Journal of Animal Science, 13: 250-252.

Herman HA, Madden FW (1963). The Artificial Insemination of dairy and beef cattle. A hand book and laboratory manual. Locas Brothers, Columbia, Missouri, USA, P. 95-105.

Husain SS (2007). Preservation of buck semen and their use in Artificial insemination for rapid genetic improvement of rural goat population. Final Report, Bangladesh Agricultural University Research Systems, Mymensingh.

Islam MR, Afroz S, Khandoker MAMY, Akter QS (2007). Motility of fresh and diluted buck semen stored at $5^{\circ} \mathrm{C}$. Bangladesh J ournal of Animal Science, 36: 9-15.
Kamal AG Ahmed A, Amel OB, Babiker A (2005). Comparative studies on reproductive performance of Nubian and Saanen bucks under the climatic conditions of Khartoum. J ournal of Animal and Veterinary Advances, 4: 942-944.

Karim FM (2008). Comparison of different diluters for frozen semen production in Black Bengal buck. MS Thesis. Department of Animal Breeding and Genetics. Bangadesh Agricultural University, Mymensingh.

Kridli RT, Tabbaa MJ, Barakch FS (2007). Seasonal variation in scrotal circumference and semen characteristics of Black Bedouin and Black Bedouin Damascus crossbred bucks. Asian Australian Journal of Animal Sciences, 20: 359-364.

Kumi-Diaka J, Nagaratnam V, Rwuaan JS (1981). Seasonal and age related changes in semen quality and testicular morphology of bulls in a tropical environment. Veterinary Research, 108: 13-15.

Maina VA, Chaudhari SUR, Mshelia, Williams (2006). Influence of Season on Semen Characteristics of Sahel Bucks in Borno State. J ournal of Applied Sciences, 6: 353-356.

Mittal JP (1982). Seasonal variation in semen quality of Barbari bucks. Indian Veterinary Journal, 59: 957-959.Moussa, A.M. 1997. Semen quality of bulls in relation to age and origin. Journal of Dairy Science, 36: 576.

Moussa AM (1997). Semen quality of bulls in relation to age and origin. Journal of Dairy Science, 36: 576.

Nazir (1988). Semen evaluation and sperm morphology-monography on reproductive pattern of Riverine buffaloes and recommendations to improve their reproductive performance at small farmer level. PARC, I slamabad, Pakistan.

Paulenz H, Soderquist L, Soltun K, Saether AP, Anderson Berg K (2003). Effect of cervical and vaginal insemination with liquid semen stored at room temperature on fertility of goats. Animal Reproduction Science, 86: 109-117.

Restall BJ (1991). Goat production in the Asian humid tropics.In:Norton, B.W., Saithanoo, D (Eds), Goat production in Asian humid tropics, 


\section{Semen quality and fertility of buck}

Proceedings of International Conference, Thailand, P. 74-83.

Saacke RG (2008). Sperm morphology: Its relevance to compensable and uneompensable traits in semen. Theriogenology, 70: 473-478.

SAS, 1998. Statistical Analysis System, Version 6.03. SAS Institute Inc. Cary NC, 25-109 USA.

Saxena VB, Tripathi SS (1984). Variation in semen quality and preservation in Jersey bulls due to seasons. Indian Journal of Animal Research. 18: $11-16$

Shamsuddin M, Rodriguez-Martinez H (1994). A simple, non traumatic culture method for the selection of spermatozoa for in vitro fertilization in the bovine. Animal Reproduction Science, 36: 51-75.

Singh DH, Sinha MP, Singh CSP, Singh RA, Singh KK (1985). Comparative study on seminal quality of pure and cross-bred bucks. Indian Journal of Veterinary Medicine, 9: 50-58.

Soderquist L (1991). Sperm characteristics and fertility in dairy Al bulls. PhD Thesis,
Department of Obstetrics and Gynaecology, Faculty of Veterinary Medicine, Swedish University of Agricultural Sciences, Uppsala, Sweden.

Srinivas M, Naidu KV, Chetty AV (2002). Seasonal variation in physical characteristics of native buck (Capra hircks) semen in Andhra Pradesh. Indian Journal of Animal Reproduction, 23: 184-186.

Stamatiadis K (1990). Seasonal variation in semen production of Alpine goats. Proceedings of $5^{\text {th }}$ Hellenic Veterinary Congress, pp. 22-23.

Sullivan JJ (1978). Morphology and motility of spermatozoa. In: Physiology of Reproduction and Artificial Insemination of Cattle. Salisbury GM, VanDemark NL, Lodge JR (eds.), Freeman and Company, Sanfrancisco, USA, P. 286-320.

Verma HK, Upadhyay MP, Pant HC (1991). A study on semen quality of Jersey bulls under temperate climate. Indian Veterinary Medical Journal, 15:11-15. 